\title{
Treatment of severe mediastinitis following cardiac surgery with omental flaps
}

\author{
Umar Imran Hamid, Harry Parissis \\ Department of Cardiothoracic Surgery, Royal Victoria Hospital, Belfast, UK
}

Correspondence to Umar Imran Hamid, umar79@hotmail.com

\section{DESCRIPTION}

The incidence of mediastinal wound infection in patients undergoing open heart surgery can be up to $4 \% . .^{1}$ A subgroup of $20-30 \%$ of those patients as per El Oakley and Wright ${ }^{2}$ develops deep sternal infections. Radical debridement is of a paramount importance, therefore sternal excision becomes a necessity in cases with severe sternal osteomyelitis. Under those circumstances various flaps have been used. ${ }^{3}$

The omentum, is a well-vascularized tissue with immunologic and angiogenic properties. It is a versatile organ with well-documented utility in the reconstruction of complex wounds and defects. In our experience it has only been used as a pedicle. The median sternotomy incision is extended for $6 \mathrm{~cm}$ towards the umbilicus and the peritoneal cavity is entered. The omentum is mobilised from the major curvature of the stomach with its blood supply (figure $1 \mathrm{~A}$ ) and is brought up in to the chest through a diaphragmatic opening; it fills the gap of the missing sternum quite adequately (figure 1B). The pectoralis major muscle based on the thoracoacromial artery is also mobilised. This facilitates apposition of the pectoral musculature and subcutaneous tissue 'en mass' on top of the omentum, in the midline. Donor site complications resulting from omental harvesting include ventral hernia, small bowel obstruction, haemorrhage, etc.
In the last decade, vacuum therapy is increasingly being employed in sternal wound infections as a first line therapy. Omental flaps are being used following failure of vac therapy or wounds with large defects. Contemplating any redo cardiac surgery is of higher risk and technically difficult especially in patients with previous mediastinitis. In patients with previous sternal flap repairs, thoracotomy may be the only route to access the heart.

In conclusion, poststernotomy mediastinitis is still one of the most feared complications after cardiac surgery and during the last 50 years several conventional treatments have been developed in order to manage these devastating infections. An optimal therapy is still yet to be determined.

Competing interests None.

Patient consent Not obtained.

\section{REFERENCES}

1. Olsen MA, Lock-Buckley P, Hopkins D, et al. The risk factors for deep and superficial chest surgical-site infections after coronary artery bypass graft surgery are different. J Thorac Cardiovasc Surg 2002;124:136-45.

2. El Oakley RM, Wright JE. Postoperative mediastinitis: classification and management. Ann Thorac Surg 1996;61:1030-6.

3. Jones G, Jurkiewicz MJ, Bostwick J, et al. Management of the infected median sternotomy wound with muscle flaps. The Emory 20-year experience. Ann Surg 1997:225:766-76; discussion 776-8.
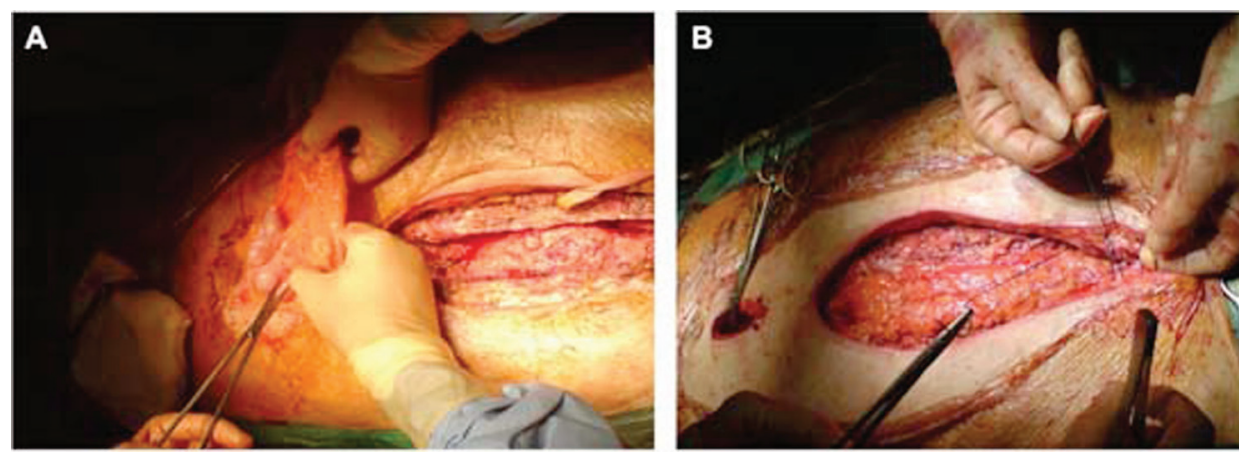

Figure 1 (A) Harvesting of omentum. (B) Omentum is placed as a pedicle through a diaphragmatic opening in the anterior mediastinum. 


\section{BMJ Case Reports}

This pdf has been created automatically from the final edited text and images.

Copyright 2011 BMJ Publishing Group. All rights reserved. For permission to reuse any of this content visit http://group.bmj.com/group/rights-licensing/permissions.

BMJ Case Report Fellows may re-use this article for personal use and teaching without any further permission.

Please cite this article as follows (you will need to access the article online to obtain the date of publication).

Hamid UI, Parissis H. Treatment of severe mediastinitis following cardiac surgery with omental flaps. BMJ Case Reports 2011;10.1136/bcr.03.2011.3971, date of publication

Become a Fellow of BMJ Case Reports today and you can:

- Submit as many cases as you like

- Enjoy fast sympathetic peer review and rapid publication of accepted articles

- Access all the published articles

Re-use any of the published material for personal use and teaching without further permission

For information on Institutional Fellowships contact consortiasales@bmjgroup.com

Visit casereports.bmj.com for more articles like this and to become a Fellow 